Extracting Low-Cost Signals of Perceived Quality Control in Community Pharmacies: A Simulated Client Study of Contraceptive Dispensing in Bogotá

Tatiana Andia, César Mantilla, Álvaro Morales, Santiago Ortiz, and Paul Rodríguez-Lesmes 
Tatiana Andia, César Mantilla, Álvaro Morales, Santiago Ortiz, and Paul Rodríguez-Lesmes

\section{Extracting Low-Cost Signals of Perceived Quality Control in Community Pharmacies: A Simulated Client Study of Contraceptive Dispensing in Bogotá}

Abstract: We determine whether community pharmacies in Bogotá produce differential quality signals, and if they are related to an objective quality measure: the compliance with prescription rules. In this quantitative descriptive study, we use the simulated client methodology $(\mathrm{N}=298)$ to assess whether Bogota's community pharmacies comply with prescription rules related to contraceptive medications. We find that one per cent of the staff at the pharmacy asked for a prescription when the pills were requested. Five per cent of the staff asked additional questions that signal knowledge or interest in the correct delivery of pills. We do not find differences by socio-economic level or type of pharmacy ownership (i.e., large firm versus independent) regarding the request of prescriptions or further questions about the pills. Concerning the aesthetic signals of quality, independent pharmacies were less likely to display a diploma of their chemist, and the likelihood that their staff wore white coats was also lower. We conclude that Bogota's community pharmacies differentiation is based on simple signals associated with a professional image, but not with actual procedures that guarantee the safety of consumers.

Keywords: pharmacies, pharmaceuticals, drugs, simulated client, contraceptive pills.

JEL Classification: I11, I15, I18.

Señales de bajo costo sobre las percepciones del control de calidad en farmacias:
un estudio de clientes simulados para el despacho de anticonceptivos en Bogotá Resumen: En este artículo determinamos si las farmacias en Bogotá producen señales diferenciales de calidad, y si están relacionadas con una medida de calidad objetiva: el cumplimiento de las reglas de prescripción. En este estudio descriptivo cuantitativo, utilizamos la metodología de clientes simulados $(N=298)$ para evaluar si las farmacias de Bogotá cumplen con las reglas de prescripción relacionadas con los medicamentos anticonceptivos. Encontramos que el uno por ciento del personal de la farmacia pidió una receta cuando se solicitaron las pildoras. El cinco por ciento del personal formuló preguntas adicionales que indican conocimiento o interés en la correcta administración de las píldoras. No encontramos diferencias por nivel socioeconómico o tipo de propiedad de la farmacia (es decir, empresa grande versus independiente) con respecto a la solicitud de recetas o preguntas adicionales sobre las pildoras. En cuanto a las señales estéticas de calidad, las farmacias independientes tenian menos probabilidades de mostrar un diploma de su quimico y la probabilidad de que su personal vistiera batas blancas también era menor. Concluimos que la diferenciación de las farmacias comunitarias de Bogotá se basa en simples señales asociadas a una imagen profesional, pero no a procedimientos reales que garanticen la seguridad de los consumidores.

Palabras clave: farmacias, fármacos, medicamentos, clientes simulados, anticonceptivos.

https://doi.org/10.17533/udea.le.n96a344243

\section{(cc) BY-NC-SA}

Este artículo y sus anexos se distribuyen por la revista Lecturas de Economía bajo los términos de la Licencia Creative Commons Atribución-NoComercial-CompartirIgual 4.0. https://creativecommons.org/licenses/by-nc-sa/4.0/ 
Signaux à faible coût sur les perceptions du contrôle de la qualité dans les pharmacies: une étude auprès de clients simulés pour la vente de contraceptifs à Bogotá

Résumé: Dans cet article, nous déterminons si les pharmacies de Bogota produisent des signaux de qualité différentiels, et s'ils sont liés à une mesure de qualité objective : le respect des règles de prescription. Dans cette étude descriptive quantitative, nous avons utilisé la méthodologie des clients simulés $(N=298)$ pour évaluer si les pharmacies de Bogota respectent les règles de prescription liées aux médicaments contraceptifs. Nous avons constaté qu'un pour cent du personnel de la pharmacie a demandé une ordonnance lorsque les pilules ont été commandées. Cinq pour cent des membres $d u$ personnel ont posé des questions supplémentaires indiquant la connaissance ou l'intérêt dans la bonne administration des pilules. Nous n'avons trouvé aucune différence selon le statut socioéconomique ou le type de proprièté de la pharmacie (c.-à-d. grande entreprise par rapport à l'entreprise indépendante) en ce qui concerne les demandes d'ordonnance ou des questions supplémentaires sur les pilules. En ce qui concerne les indices de qualité esthétique, les pharmacies indépendantes étaient moins susceptibles de montrer un diplôme de leur chimiste et leur personnel était moins susceptible de porter des blouses blanches. Nous concluons que la différenciation des pharmacies communautaires à Bogota est basée sur des signaux simples associés à une image professionnelle, mais pas avec des procédures réelles qui garantissent la sécurité des consommateurs.

Mots clés: pharmacies, produits pharmaceutiques, médicaments, clients simulés, contraceptifs

Cómo citar / How to cite this item:

Andia T., Mantilla C., Morales Álvaro, Ortiz S., \& Rodriguez-Lesmes P. (2022). Extracting Low-Cost Signals of Perceived Quality Control in Community Pharmacies: A Simulated Client Study of Contraceptive Dispensing in Bogotá. Lecturas de Economía, 96, 9-30. https://doi.org/10.17533/udea.le.n96a344243 


\title{
Extracting Low-Cost Signals of Perceived Quality Control in Community Pharmacies: A Simulated Client Study of Contraceptive Dispensing in Bogotá
}

\author{
Tatiana Andia $\oplus^{\mathrm{a}}$, César Mantilla $\oplus^{\mathrm{b}}$, Álvaro Morales ${ }^{\mathrm{c}}$, Santiago \\ Ortiz ${ }^{\mathrm{d}}$, and Paul Rodríguez-Lesmes $\oplus^{\mathrm{e}}$
}

-Introduction. -I. Context: Bogota's community pharmacies market. -II. Methods. -III. Results. -Discussion and conclusions. -Acknowledgement. -References

Original manuscript received on 28 October 2020; final version accepted on 05 August 2021

\section{Introduction}

Community pharmacies are key components of the healthcare systems of Low- and Middle-income Countries (hereinafter LMICs), as they are often the first line of contact for citizens with the health sector (World Health Organization, 1997). In the pursuit of universal healthcare coverage, pharmacies need to meet some basic standard of quality, which is usually hard to measure in LMICs given the absence or low quality of administrative data sources (Das et al., 2016). In these contexts, methods such as simulated clients and standardized patients (Madden et al., 1997; Watson et al., 2006;

a Tatiana Andia: Associate Professor at Universidad de los Andes, Facultad de Ciencias Sociales,

Bogotá, Colombia. E-mail: tandia@uniandes.edu.co

https://orcid.org/0000-0003-1805-2549

b César Mantilla: Associate Professor at Universidad del Rosario, Facultad de Economía, Bogotá, Colombia. E-mail: cesar.mantilla@urosario.edu.co

https://orcid.org/0000-0002-4752-4448

c Álvaro Morales: Ministerio de la Salud y la Protección Social, Bogotá, Colombia.

E-mail: alvaro0126@gmail.com

d Santiago Ortiz: Research Assistant at Universidad del Rosario, Facultad de Economía, Bogotá, Colombia. E-mail: santiago.ortizo@urosario.edu.co

https://orcid.org/0000-0001-9939-0608P

e Paul Rodríguez-Lesmes: Associate Professor at Universidad del Rosario, Facultad de Economía, Bogotá, Colombia. E-mail: paul.rodriguez@urosario.edu.co

https://orcid.org/0000-0003-1058-3062 
Andia, Mantilla, Morales, Ortiz, and Rodríguez-Lesmes: Extracting Low-Cost Signals...

Kwan et al., 2019) can provide measures of healthcare quality in a firsthand, standardized, and controlled fashion relying on observed behaviour. The use of the simulated client methodology (SCM) is becoming extensively employed to evaluate the dispensing and sales of antibiotics, and knowledge and management of diarrhoea and sexually transmitted diseases (STDs) in pharmacies (Smith, 2009; Wafula et al., 2012; Miller \& Goodman, 2016), and in the context of LMICs can also provide information about the functioning of informal markets without posted prices (Zamora et al., 2021).

Previous findings suggest that quality standards in pharmacies are often deficient. In the South American case, the picture looks more worrying: 78\% of antibiotics are dispensed without prescription, compared with an average of $62 \%$ worldwide (Auta et al., 2019). In the Colombian case, Vacca et al. (2011) find that $80 \%$ of the sampled pharmacies in Bogota do not demand a prescription. In a related survey-based study conducted with pharmacy vendors, $58 \%$ of the respondents declared that clients "hardly ever" present the prescription, and $62 \%$ report directly recommending the use of antibiotics (Castro \& Molineros, 2018).

As actual quality is hard to be determined by consumers, competition between community pharmacies is based on location (convenience) and on prices. Nevertheless, they can find other margins of competition, especially in urban areas of high density (Martins \& Queirós, 2015). For instance, they can provide more services, but also can try to appeal to consumer loyalty and to produce a positive image of their business (Pestun, et al., 2017; Heinsohn \& Flessa, 2013). Pharmacies can thus produce "quality-signals" in this context, suggesting to their potential consumers that their establishment should be trusted, and that it might be of higher quality than their competitors (Perepelkin \& Zhang, 2011).

The purpose of this quantitative descriptive study is to explore prescription control in the case of contraceptive pills in Colombian community pharmacies, and its connection with the quality signals. Easy access to contraception is associated with decreasing abortions and reduced unplanned and mistimed pregnancies, improving women's overall sexual and reproductive health and reducing maternal deaths (Peipert et al., 2012; Jones, 
2015; Ahmed et al. 2012). While this argument suggests that prescription is an actual barrier to contraception access, the existence of contraindications based on the health history of women is the main argument for not allowing this medication to be over-the-counter medications (OTC) in many countries (Grindalay, Burns \& Grossman, 2013; Xu et al., 2014). Thus, understanding access to contraceptives at community pharmacies can provide insights about the quality of care around a crucial health intervention for a woman.

Although a prescription is required for the dispensing of contraceptives in Colombia, we expect less control for these medicines for two reasons: their excessive use does not pose a global collective problem, as in the case of antibiotics (Hollis \& Maybarduk, 2015; Roope et al., 2019); and the regularity in consumption makes monthly prescription redundant. To test these hypotheses and understand contraceptive dispensing practices, we implement the Simulated Client Method (hereinafter SCM) in a sample of community pharmacies in Bogota, a city with more than 3000 community pharmacies. ${ }^{1}$

We devised a script in which the simulated client entered a pharmacy and asked for a specific brand of contraceptive pill that was prescribed to the younger sister. We collected information on whether the medical prescription was requested by the vendor, whether the operating banner was placed in a visible place in the pharmacy, whether the vendor wore a white coat, and whether the inventory was handled with a computer, an electronic cash register, or manually (i.e., a notebook or a non-computerized cash register). The first of these metrics is standard in the studies employing the SCM. The remaining three are included in our report because they can be interpreted as additional signals of quality standards in the community pharmacies.

We find very small compliance rates with the request of the prescription of the contraceptive pills (1\%). For low-cost signals of quality, associated with a professional image and not with the delivery procedures, we find a higher compliance: diplomas for the handling of pharmaceutical products are visible in $32 \%$ of the audited pharmacies, and $85 \%$ of vendors wore a white coat during the visit.

1 See https://perma.cc/Y9Q4-UYVY to understand how community pharmacies work and their importance in Colombian neighborhoods. 
Our contribution with this study is twofold. First, we show for a pharmaceutical product different from antibiotics that the request of prescriptions is almost absent. Moreover, the contraceptive brand employed in our simulated client study is often used for acne purposes. We did not find that pharmacists take this information into account either. By contrast, our second contribution is to show that pharmacies comply better with more aesthetic signals of perceived quality (i.e., displaying a diploma or wearing a white coat), even though these are unrelated to the abovementioned signals of quality.

The remainder of this paper is organized as follows. Section 1 describes Bogotás community pharmacies market context. Section 2 explains our methodological approaches for collecting and analysing the data of the pharmacies. Section 3 presents the main results, which are finally discussed and concluded.

\section{Context: Bogota's community pharmacies market}

There are three medicine supply systems in Colombia: the institutional sector (directed to health care providers), the mandatory-insurers sector, and the private sector. Community pharmacies are part of the private sector, a standard retail market which has a single supply chain. Community pharmacies can be fully integrated into a large firm which buys from laboratories and pharmaceutical importers (a chain), or they can also be independent but affiliated with large cooperatives which act as single-buyers in the wholesale market (Mendoza-Ruiz et al., 2017).

If a consumer has a prescription from their mandatory insurer (nearly universal coverage of the system), they could visit their insurer pharmacy but also use the prescription to get most medications in their local community pharmacy. Insurer pharmacies (with restricted locations) provide exact quantities, have fixed prices depending on income, and provide no choice between brands of the prescribed medicines. Moreover, they are not allowed to sell any other type of product. Therefore, the main role of community pharmacies is to act as convenience stores that allow consumers to get medication close to their homes or workplace and choose between brands 
of these products. Community pharmacies also sell OTC and often provide other products such as ice-creams or beauty products (Gutierrez et al., 2020).

Regulation makes clear that medication should be sold under clear and non-amended prescriptions (Decree 1950 of 1964), except if the box has a clear sign indicating that the product is OTC. In terms of personnel, pharmacies require a licensed technical director (community pharmacist) trained in either pharmaceutical chemistry or pharmacy management, which could be obtained after formal vocational or professional college-level studies (Decree 780 of 2016). Qualification requirements are stricter if the pharmacy sells medication under special controls (e.g., opiates) of for inpatient treatment.

Territorial Health Entities are in charge of inspection, monitoring and control with the purpose of increasing coverage without sacrificing safety. In the case of Bogota, pharmacies must have an approval from the local environmental regulation agency, as well as clear written procedure manuals concerning storage and inventories, medication handling and dispensation, and waste handling. Spatial requirements on pharmacies include (i) floors, roofs, and walls, resistant to humidity; (ii) a physical area of at least $20 \mathrm{~m}^{2}$, including a designated restricted area non-accessible to clients; and (iii) the presence of outdoor signage.

Compliance with the rules described above depends largely on the audit capacity. The spatial requirements mentioned above, including the minimum physical area and the presence of outdoor signage, are typically met (Gutierrez et al., 2020). By contrast, there is low compliance with procedures such as selling non-OTC medication without a prescription, given the considerably large monitoring costs. For instance, from a sample of pharmacies in Bogota, antibiotics were sold without the need for a prescription, and without discussions about potential allergies (Vacca et al., 2011).

Although not mandatory, pharmacy managers place the diploma in a degree related to pharmaceutical chemistry or other certifications for handling pharmaceutical products in a visible area. The evidence that pharmacies sell non-OTC medication without prescription contrasts with their engagement with these non-mandatory signals of quality. 
Andia, Mantilla, Morales, Ortiz, and Rodríguez-Lesmes: Extracting Low-Cost Signals...

\section{Methods}

The use of the SCM allows us to present the same case to multiple pharmacies in a blinded fashion. An evident advantage is the reduction of Hawthorne effects and social desirability biases in behaviour or survey responses (Madden et al., 1997; Watson et al., 2006; Kwan et al., 2019). In the particular context of community pharmacies, reducing these effects associated with observability are important to prevent pharmacists preparing for an inspection, or avoiding a temporary compliance with safety and delivery protocols because they were aware of an incoming scrutiny.

We developed a standardized script to detect whether the prescription was requested when acquiring contraceptive pills. The SCM, or audit study, was executed as follows. The simulated client entered the pharmacy when there was at least one available vendor ${ }^{2}$ and said that the physician prescribed to her/his younger sister a specific brand of contraceptive pill. ${ }^{3}$ The simulated clients were instructed to collect information on the following variables, used as proxies of quality: (i) whether the prescription was requested, (ii) whether a diploma or any other certification for handling pharmaceutical products was visible, (iii) whether the vendor wore a lab coat, and (iv) whether a computer or an electronic cash register was visible. Moreover, the two high-end contraceptive brands quoted in the audit study are seldom prescribed for acne reasons. Hence, we also coded (v) whether the pharmacist posed additional questions regarding the reason why those specific brands were prescribed. Note that the listed items (i) and (v) (i.e., prescription request and further questions about the prescription) are proxies of quality signals related to standardized protocols for delivery of pharmaceuticals, whereas the other three information items, (ii), (iii) and

2 We ensured the availability of at least one vendor to not impose queuing times to actual customers.

3 Community pharmacies were randomly assigned to two different treatments differing in the high-end brand that was requested. Each brand has a different active component, Dienogest and Drosperinona, and both are typically prescribed in cases of acne. We explore the brand differences in a related study, in which the SCM is employed to study the effects of a contraceptive price cap regulation. The full details on the request of contraceptive pills are described in detail in Andia et al. (2020a). 
(iv), are related to signals of professional image that do not positively impact the safety of delivery protocols.

We developed a sampling strategy based on the distance of pharmacies to the stations of the mass transportation system in the city. Our purpose was to include, in a systematic manner, pharmacies located in areas with a considerable influx of visitors. We based this methodological decision on the fact that, since we were collecting data on the prices of contraceptive products before and after a price regulation ${ }^{4}$, stock rotation was important to guarantee that changes in prices at the distributor level would have been rapidly incorporated at the pharmacy level. Figure 1 displays the geographic location of the originally sampled pharmacies. The original sampling of pharmacies was completed using Google Maps. Some of the registered stores were moved or were permanently closed. We also skipped the audit of the drug stores assigned to 10 of the 143 stations of the transportation system in Bogota for security reasons. We audited a total of 298 drug stores, out of an initial list of 354 locations. All the simulated client visits took place in December 2019.

The audit visits to community pharmacies were performed by 23 different research assistants in the role of simulated clients (11 men and 12 women). All the simulated clients were in an age range of 20 to 35 years old. They were assigned in pairs to different lines of the mass transportation system. The pharmacies in a zone (or subzone) were randomly assigned to the two simulated clients in each pair. On average, each person visited 12.4 pharmacies (std. dev. 8.43). ${ }^{5}$

4 The data collection also involved another project exploring the change in price of contraceptive pills at the counter, before and after a regulation that regulated prices at the start of the distribution channel. For more details, see Andia et al. (2020).

5 Data and code are publicly available in the repository

https://doi.org/10.34848/FK2/8TMRLC (Andia et al., 2020b). 
Andia, Mantilla, Morales, Ortiz, and Rodríguez-Lesmes: Extracting Low-Cost Signals...

\section{Results}

\section{A. Characteristics of the audited pharmacies}

Table 1 summarizes the characteristics of the 298 audited pharmacies. We divided the stations of the transportation system, Transmilenio, into three geographic areas accounting for roughly the same proportion of visited pharmacies. The high socioeconomic strata ${ }^{6}$ (SES) are concentrated in the north and west zones. Thirty-nine per cent of the visited pharmacies are located in areas classified as being of high SES. Regarding ownership of the visited pharmacies, $62 \%$ of them were independent and the remaining $38 \%$ belonged to a chain. This prevalence of small independent pharmacies is also evident in the large proportion of pharmacies in which, by the time of the visit, there was only one seller $(52 \%)$. In terms of the inventory management, the simulated clients observed that in $79 \%$ of the visited pharmacies the inventory was handled by computer and another $16 \%$ with electronic cash registers. Moreover, 53\% offered services or even sold goods over and above pharmaceutical products or basic health services. This includes beauty products, photocopies, toys, groceries, among others. Most pharmacies offer packed ice-creams, sodas or bottled water, as this has been a traditional distribution channel of these firms.

Regarding the interactions between the seller and the simulated client, we find that $51 \%$ of the sellers were female. The perceived age of the sellers fell in our " $30-50$ years old" range in 55\% of the cases, and sellers looked older than 50 years in $19 \%$ of the cases. Finally, since most of the pharmacies were small and our protocols required that simulated clients waited outside (or came back in 5-10 minutes) if the pharmacy had multiple clients, we find that in $54 \%$ of the interactions there were no other customers at the time of the audit, and in $32 \%$ of the cases there were between one and two additional customers.

6 Municipalities in Colombia have a stratification system that classify districts from Stratum 1 (the poorest) to Stratum 6 (the richest), to provide cross-class subsidies in the utilities and to focalize government programs. We grouped Strata 4, 5 and 6 as "high" and Strata 2 and 3 as "low." 
Figure 1. Geographic location of the sample of pharmacies

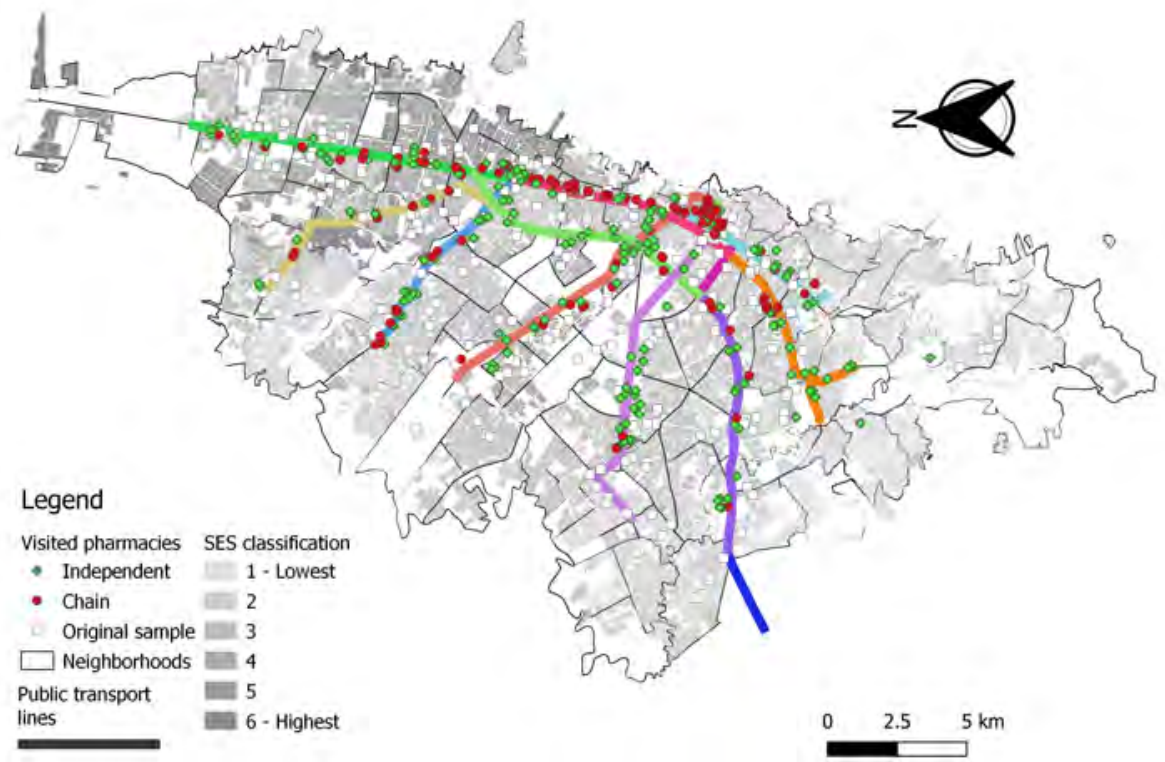

Source: Own calculations based on data records from SCM.

Table 1. Characteristics of visited pharmacies

\begin{tabular}{lcc}
\hline Characteristics & $(\%)$ & Obs. \\
\hline Transmilenio zone & & \\
North & 29.3 & \\
South & 38.0 & 297 \\
West & 33.7 & \\
SES level & & \\
Low & 61.4 \\
\hline
\end{tabular}

Lecturas de Economía -Lect. Econ. - No. 96. Medellín, Enero-Junio 2022 
Andia, Mantilla, Morales, Ortiz, and Rodríguez-Lesmes: Extracting Low-Cost Signals...

Table 1. Characteristics of visited pharmacies

\begin{tabular}{|c|c|c|}
\hline Characteristics & $(\%)$ & Obs. \\
\hline High & 38.6 & 298 \\
\hline \multicolumn{3}{|l|}{ Pharmacy type } \\
\hline Independent & 62.1 & \\
\hline Chain & 37.9 & 298 \\
\hline \multicolumn{3}{|l|}{ Number of sellers } \\
\hline One & 52.2 & \\
\hline Two & 34.7 & 297 \\
\hline Three or more & 13.1 & \\
\hline \multicolumn{3}{|c|}{ Inventory management system } \\
\hline Computer & 79.3 & \\
\hline Electronic cash register & 16.3 & 294 \\
\hline Other & 4.4 & \\
\hline \multicolumn{3}{|l|}{ Client's gender } \\
\hline Male & 48.99 & \\
\hline Female & 51.01 & 298 \\
\hline \multicolumn{3}{|l|}{ Seller's gender } \\
\hline Male & 48.6 & \\
\hline Female & 51.4 & 298 \\
\hline \multicolumn{3}{|l|}{ Seller's age range (years) } \\
\hline $18-29$ & 25.8 & \\
\hline $30-50$ & 55.4 & 298 \\
\hline$>50$ & 18.8 & \\
\hline \multicolumn{3}{|c|}{ Other customers in pharmacy } \\
\hline No & 54.0 & \\
\hline One or two & 32.2 & 296 \\
\hline Three or more & 13.8 & \\
\hline
\end{tabular}

Continued on next page 
Table 1. Characteristics of visited pharmacies

\begin{tabular}{lll}
\hline Characteristics & $(\%)$ & Obs. \\
\hline Other services & & \\
Groceries store & 52.7 & \\
Only health services & 47.3 & 298 \\
\hline
\end{tabular}

Notes: In our SCM, we used a sample of 298 observations. However, in some cases, the simulated clients did not report the information in some of the characteristics, so we report that as a missing value reducing the total available observations for some characteristics.

Source: Own calculations based on data records from SCM.

Table 2. Compliance rate across pharmacies for four different outcomes $(N=298)$

\begin{tabular}{lcccc}
\hline & $\begin{array}{c}\text { Requested } \\
\text { prescription (\%) }\end{array}$ & $\begin{array}{c}\text { Additional } \\
\text { questions (\%) }\end{array}$ & $\begin{array}{c}\text { Visible banner } \\
\text { or diploma (\%) }\end{array}$ & $\begin{array}{c}\text { Vendor wore } \\
\text { coat (\%) }\end{array}$ \\
\hline $\begin{array}{l}\text { Average compliance rate } \\
\text { By pharmacy type }\end{array}$ & 1.01 & 5.03 & 32.21 & 84.56 \\
$\quad$ Independent & 1.08 & 3.78 & 23.8 & 76.7 \\
Chain & 0.87 & 7.07 & 46.01 & 97.3 \\
$\begin{array}{l}p \text {-value Chi-squared test } \\
\text { By SES Level }\end{array}$ & 0.869 & 0.207 & $<0.01$ & $<0.01$ \\
Low & 1.09 & 6.01 & 34.9 & 82.5 \\
High & 0.87 & 3.47 & 27.8 & 87.8 \\
$\quad$-value Chi-squared test & 0.851 & 0.33 & 0.199 & 0.217 \\
By other offered services & & & & 85.35 \\
Sells groceries & 0 & 5.73 & 35.03 & 83.68 \\
Only health services & 2.18 & 4.25 & 29.07 & 0.692 \\
\hline -value Chi-squared test & 0.066 & 0.56 & 0.272 & \\
\hline
\end{tabular}

Source: Own calculations based on data records from SCM. 
Andia, Mantilla, Morales, Ortiz, and Rodríguez-Lesmes: Extracting Low-Cost Signals...

Table 3. Correlation across four different outcomes $(N=298)$

\begin{tabular}{lcccc}
\hline & $\begin{array}{c}\text { Request } \\
\text { prescription }\end{array}$ & $\begin{array}{c}\text { Additional } \\
\text { questions }\end{array}$ & $\begin{array}{c}\text { Visible banner } \\
\text { or diploma }\end{array}$ & $\begin{array}{c}\text { Vendor wore } \\
\text { coat }\end{array}$ \\
\hline Request prescription & 1.00 & $0.2843^{*}$ & 0.0743 & 0.0431 \\
Additional questions & 1.00 & 0.0384 & 0.0559 \\
Visible banner or diploma & & 1.00 & 0.0560 \\
Vendor wore coat & & & & 1.00 \\
\hline
\end{tabular}

Notes: Significance level: ${ }^{*} p<0.05$.

Source: Own calculations based on data records from SCM.

\section{B. Compliance rates}

Table 2 reports the compliance rate for four different outcomes of interest. We find that in $1 \%$ of the visited pharmacies the vendor requested the prescription. In $5 \%$ of the cases the vendor asked additional questions about the younger sister for whom the pills were prescribed. The majoritarian question was if the prescription corresponded to acne problems $(8 / 15)$, followed by the sister's age (6/15), and whether this was the first time that the sister had taken contraceptive pills $(1 / 15) .{ }^{7}$ We also find that $32 \%$ of the pharmacies held a visible operating banner or a diploma certifying the expertise for handling pharmaceutical products, and that $85 \%$ of vendors were wearing a white coat at the time of the interaction.

We also report in Table 2 whether we observe differences in these outcomes by pharmacy type (i.e., independent or belonging to a chain), by the socio-economic status of the block in which the pharmacy is located (high SES versus low SES), and by the extent of offered services (only health services versus selling groceries). We do not find any difference across pharmacy type for the outcome variables with the lowest compliance rate, the request of a prescription and further questions about the younger sister for whom the pills are being bought. By contrast, we find that pharmacies

7 In an additional case, not included in this analysis because this is not a measure of quality, the vendor asked if the pills were really for the client's sister. 
belonging to a chain were more likely to hold a visible operating banner or diploma (46\%) than the independent pharmacies $(24 \%)$, and it was also more likely that in these pharmacies the vendor wore a white coat at the time of the interaction ( $97 \%$ compared to $77 \%$ in the independent pharmacies).

We do not find differences for any of the four outcomes when comparing high versus low SES levels. Regarding the type of services offered by community pharmacies, the few cases in which the prescription was requested occurred in pharmacies that only offered health services. The $p$-value of the associated test is 0.066 . We do not find any other statistically significant difference for the remaining measures of quality reported in this table.

Table 3 complements these findings with a report of the correlations between the four outcome variables. All the correlations are low (i.e., lower than 0.100 ) except for the correlation between requesting the prescription and asking further questions about the specific brand of pill. The latter correlation is 0.28 and it is statistically significant at the $10 \%$ level. In general, we confirm that aesthetic quality signals are not correlated with more objective quality signals.

\section{Discussion and conclusions}

Our main result is that community pharmacies, whether independent or belonging to large chains, do not comply with the basic regulation of requesting a prescription. This is in line with the classification made by Grindlay et al. (2013) of Colombia as a market where oral contraceptives are considered to be informally available without a prescription. This might be problematic in our studied product, as the medication is intended to be used for young women and the easy access in the pharmacy to these products may result in a decreased interest in seeking professional reproductive health preventive care (Rafie et al., 2016). However, as argued by Grindlay et al. (2013), lower barriers can expand access to contraceptives leading to the positive outcomes previously discussed in the introduction. A complementary finding is that pharmacy quality signals are limited to more aesthetic patterns, such as showing a diploma certifying the handling of pharmaceutical products or interacting with customers while wearing a white coat. 
Interestingly, we do not observe differences across SES. A conjecture, exante valid, is that highly educated consumers (who live in high SES areas) would exert more pressure on their local pharmacies to meet the highest standards in quality control. The lack of a correlation between SES and signals of quality suggests that this pressure is absent, at least for contraceptive pills.

A limitation in our study is that the SCM was applied with a single pharmaceutical product. Community pharmacy vendors may assign a low risk to the use of contraceptive pills without prescription or, alternatively, they are satisfied with the fact that in our script we explicitly say that the pills were prescribed by a doctor. It could be the case that for other pharmaceutical products, such as antibiotics, the vendors exhibit higher compliance in the prescription request. However, Vacca et al. (2011) show us that for antibiotics, where the chances of complications are larger, a similar pattern holds.

Pharmacies appear to acknowledge the importance of quality signals. Unfortunately, aesthetic rather than procedural signals are prevalent. Sanitary authorities should move beyond checking the physical characteristics of the pharmacy, or the existence of procedure manuals. Inspection strategies assessing the quality of the interaction with customers, without sacrificing the blinded nature of the audit, pose an interesting regulatory challenge. Moreover, educational campaigns directed to chemists of community pharmacists should emphasize the importance of complying with the nonOTC procedures.

\section{Acknowledgements}

We would like to thank the members of Salud Visible (Universidad de los Andes), Universities Allied for Essential Medicines (Universidad Nacional), and Jóvenes Investigadores team from Universidad del Rosario for taking part as simulated clients: Juan Pablo Baquero, Emilia Cardenas, Liliana Cortés, Nicolas Currea, Sara Delgado, María Camila Díaz, Diana Jany, Karen Liseth Franco, Daniela Gonzalez, Christian Leal, Daniela López, Kevin López, Luisa Medieta, Valentina Muñoz Bernal, Elsy Ramírez, Gustavo Rojano, Steffanny Romero, Juliana Sánchez, Andrea Juliana Silva, Pablo Toro, Jhonathan Vanegas, María Gabriela Vargas, Juan Pablo Vega, Santiago 
Villanueva, and Juan Diego Zapata. Financial Support from the programs "Inclusión productiva y social: programas y políticas para la promoción de una economía formal, código 60185, que conforma la Alianza EFI, bajo el Contrato de Recuperación Contingente No. FP44842-2202018" and "Universidad del Rosario, Fondo de Arranque: Economía de la salud, temas en política farmacéutica" are gratefully acknowledged.

\section{References}

Ahmed, S., Li, Q., Liu, L., \& Tsui, A. O. (2012). Maternal Deaths Averted by Contraceptive Use: An Analysis of 172 Countries. Lancet, 380 (9837), 111-125. https://doi.org/10.1016/S0140-6736(12)60478-4

Andia, T., Mantilla, C., Morales, A., Ortiz, S., \& Rodríguez-Lesmes, P. (2020a). Does Price-Cap Regulation Work for Increasing Access to Contraceptives? Aggregate- and Pharmacy-Level Evidence from Colombia [working paper 018484 , Universidad del Rosario]. https://ideas.repec. $\mathrm{org} / \mathrm{p} / \mathrm{col} / 000092 / 018484 . \mathrm{html}$

Andia, T., Mantilla, C., Morales, A., Ortiz, S., \& Rodríguez-Lesmes, P. (2020b). "Extracting low-cost signals of quality control in community pharmacies: a simulated client study in Bogota", https://doi.org/10.3 4848/FK2/8TMRLC, Universidad del Rosario, V5.

Auta, A., Hadi, M. A., Oga, E., Adewuyi, E. O., Abdu-Aguye, S. N., Adeloye, D., StricklandHodge, B., \& Morgan, D. J. (2019). Global Access to Antibiotics Without Prescription in Community Pharmacies: A Systematic Review and Meta-Analysis. Journal of Infection, 78(1):818. https://doi.org/10.1016/j.jinf.2018.07.001

Castro Espinosa, J., \& Molineros, L. F. (2018). Qualification and Experience from Drugstore Sellers for the Dispensing of Amoxicillin in a Commune of Santiago de Cali, Colombia. Revista Colombiana de Ciencias Quimico-Farmaceuticas, 47(1), 53-70. https://doi.org/10.1 5446/rcciquifa.v47n1.70658 
Andia, Mantilla, Morales, Ortiz, and Rodríguez-Lesmes: Extracting Low-Cost Signals...

Das, J., Holla, A., Mohpal, A., \& Muralidharan, K. (2016). Quality and Accountability in Health Care Delivery: Audit-Study Evidence from Primary Care in India. American Economic Review, 106(12), 3765-99. https://doi.org/10.1257/aer.20151138

Grindlay, K., Burns, B., \& Grossman, D. (2013). Prescription Requirements and Over-The-Counter Access to Oral Contraceptives: A Global Review. Contraception, 88(1), 91-96. https://doi.org/10.1016/j.co ntraception.2012.11.021

Gutierrez, L., Medina, I., Ureña, J., and Rodríguez-Lesmes, P. (2020). Reporte de la Primera Encuesta Nacional de Microestablecimientos Comerciales y de Servicios. Serie Alianza EFI. Universidad del Rosario, Universidad Minuto de Dios, Fundación Capital, (1). https://doi.org/ 10.34848/FK2/RD5NIK

Heinsohn, J. G., \& Flessa, S. (2013). Competition in the German Pharmacy Market: An Empirical Analysis. BMC health services research, 13(1), 407. https://doi.org/10.1186/1472-6963-13-407

Hollis, A., \& Maybarduk, P. (2015). Antibiotic Resistance is A Tragedy of the Commons that Necessitates Global Cooperation. The Journal of Law, Medicine \& Ethics, 43(3), 33-37. https://doi.org/10.1111/jlme.12272

Jones, K. M. (2015). Contraceptive Supply and Fertility Outcomes: Evidence from Ghana. Economic Development and Cultural Change, 64 (1), 3169. https://doi.org/10.1086/682981

Kwan, A., Daniels, B., Bergkvist, S., Das, V., Pai, M., \& Das, J. (2019). Use of Standardised Patients for Healthcare Quality Research in Lowand Middle-Income Countries. BMJ Global Health, 4(5), e001669. https://doi.org/10.1136/bmjgh-2019-001669

Madden, J. M., Quick, J. D., Ross-Degnan, D., \& Kafle, K. K. (1997). Undercover Careseekers: Simulated Clients in The Study of Health Provider Behavior in Developing Countries. Social Science \& Medicine, 45(10), 1465-1482. https://doi.org/10.1016/s0277-9536(97)00076-2 
Martins, L., \& Queirós, S. (2015). Competition Among Pharmacies and The Typology of Services Delivered: The Portuguese Case. Health Policy, 119(5), 640-647. https://doi.org/10.1016/j.healthpol.2015.03.001

Mendoza-Ruiz, A., Acosta, A., Escamilla, E. P. V., \& Torres, M. C. L. (2017). Pharmaceutical Policy in Colombia. In Babar, Z. (eds) Pharmaceutical Policy in Countries with Developing Healthcare Systems (pp. 193-219). Springer. https://doi.org/10.1007/978-3-319-51673-8_10

Miller, R., \& Goodman, C. (2016). Performance of Retail Pharmacies in Lowand Middle-income Asian Settings: A Systematic Review. Health policy and planning, 31(7), 940-953. https://doi.org/10.1093/heapol/czw007

Peipert J. F, Madden, T., Allsworth. J. E., \& Secura, G. M. (2012). Preventing Unintended Pregnancies by Providing No-Cost Contraception. Obstet Gynecol,120(6), 1291-7. https://doi.org/10.1097/aog.0b013e318273 eb56

Presidencia de la República. (1964, July 31 ${ }^{\text {st }}$ ). Decreto 1950. Por el cual se reglamenta la Ley 23 de 1962, sobre ejercicio de la profesión de QuimicoFarmacéutico y se dictan otras disposiciones. https://www.mineducacion .gov.co/1759/articles-103753_archivo_pdf.pdf

Presidencia de la República. (2016, May, 6 ${ }^{\text {st }}$ ). Decreto 780. Por medio del cual se expide el Decreto Único Reglamentario del Sector Salud y Protección Social. https://www.minsalud.gov.co/Normatividad_Nuevo/Decreto \%200780\%20de\%202016.pdf

Rafie, S., Kelly, S., Gray, E. K., Wong, M., Gibbs, S., \& Harper, C. C. (2016). Provider Opinions Regarding Expanding Access to Hormonal Contraception in Pharmacies. Women's Health Issues, 26(2), 153-160. https://doi.org/10.1016/j.whi.2015.09.006

Roope, L. S., Smith, R. D., Pouwels, K. B., Buchanan, J., Abel, L., Eibich, P., Butler, C. C., San Tan, P., Walker, A. S., Robotham, J. V., et al. (2019). The Challenge of Antimicrobial Resistance: What Economics Can Contribute. Science, 364(6435), eaau4679. https://doi.org/10.1 126/science.aau4679 
Andia, Mantilla, Morales, Ortiz, and Rodríguez-Lesmes: Extracting Low-Cost Signals...

Perepelkin, J., \& Di Zhang, D. (2011). Brand Personality and Customer Trust in Community Pharmacies. International journal of pharmaceutical and healthcare marketing, 5, 175-193. https://doi.org/10.1108/17506121 111172194

Pestun, I. V., Mnushko, Z. M., \& Datkhayev, U. M. (2017). Social, Ethical and Economic Aspects of Competition Pharmacies. APMAUNR KAAXCTAHA, (9), 37-40. https://www.elibrary.ru/item.asp?id= 37146299

Smith, F. (2009). The Quality of Private Pharmacy Services in Low and Middle-Income Countries: A Systematic Review. Pharmacy World \& Science, 31(3),351-361. https://doi.org/10.1007/s1 1096-009-9294-z

Vacca, C., Nino, C., \& Reveiz, L. (2011). Restriction of Antibiotic Sales in Pharmacies in Bogotá, Colombia: A Descriptive Study. Revista Panamericana de Salud Pública, 30(6), 586-591. https://doi.org/10 .1590/S1020-49892011001200015

Xu, H., Eisenberg, D. L., Madden, T., Secura, G. M., \& Peipert, J. F. (2014). Medical Contraindications in Women Seeking Combined Hormonal Contraception. American journal of obstetrics and gynecology, 210(3), 210-e1. https://doi.org/10.1016/j.ajog.2013.11.023

Wafula, F. N., Miriti, E. M., \& Goodman, C. A. (2012). Examining Characteristics, Knowledge and Regulatory Practices of Specialized Drug Shops in Sub-Saharan Africa: A Systematic Review of The Literature. BMC health services research, 12(1), 223. https://doi.org/ $10.1186 / 1472-6963-12-223$

Watson, M. C., Norris, P., \& Granas, A. (2006). A Systematic Review of The Use of Simulated Patients and Pharmacy Practice Research. International Journal of Pharmacy Practice, 14(2),83-93. https://doi. org/10.1211/ijpp.14.2.0002

World Health Organization (1997). The Role of the Pharmacist in The Health Care System: Preparing the Future Pharmacist: Curricular Development: 
Report of a Third WHO Consultative Group on the Role of the Pharmacist [Technical report]. Vancouver, Canada, 27-29 August, Geneva.

World Health Organization. https://apps.who.int/iris/handle/10665/63817

Zamora, P., Mantilla, C., \& Blanco, M. (2021). Price Discrimination in Informal Labor Markets in Bogotá: An Audit Experiment During the 2018 FIFA World Cup. Journal for Labour Market Research, 55(1), 1-24. https://doi.org/10.1186/s12651-021-00285-1 